This is an accepted manuscript. The original article has been published in Patient Education and Counseling. 2017, vol. 100, issue 10, pp. 1828-1841. DOI: https://doi.org/10.1016/j.pec.2017.05.003

\title{
Group members' questions shape participation in health counselling and health education
}

Aija Logren $^{a *}$, Johanna Ruusuvuoria, Jaana Laitinen ${ }^{\mathrm{b}}$

a Faculty of Social Sciences, University of Tampere, Tampere, Finland

Email: aija.logren@uta.fi, johanna.ruusuvuori@uta.fi

${ }^{b}$ Finnish Institute of Occupational Health, Oulu, Finland

Email: jaana.laitinen@ttl.fi

* Corresponding author at Faculty of Social Sciences, University of Tampere,

Linna Building, 33014 Tampere, Finland

Email: aija.logren@uta.fi

Telephone: +358 503187110 


\begin{abstract}
Objective: This study examines how group members' questions shape member participation in health counselling and health education groups.

Methods: The study applies conversation analytic principles as a method. The data consist of video-recorded health education lessons in secondary school and health counselling sessions for adults with a high risk of Type 2 diabetes.

Results: Group members' questions accomplish a temporary change in participatory roles. They are used to 1) request counselling, 2) do counselling or 3) challenge previous talk. They are usually treated as relevant and legitimate actions by the participants, but are occasionally interpreted as transitions outside the current action or topic.

Conclusion: Group members' questions result in a shift from leader-driven to member-driven discussion. Thus they constitute a pivot point for detecting changes in participation in group interventions.

Practice Implications: Observing the occurrence of group members' questions helps group leaders to adjust their own actions accordingly and thus facilitate or guide group participation. Comparison of the type and frequency of members' questions is a way to detect different trajectories for delivering group interventions and can thus be used to develop methods for process evaluation of interventions.
\end{abstract}

\title{
Keywords
}

applied conversation analysis, client initiation, group counselling, group discussion, health education, interaction, multiparty interaction, participant-centred communication, participation, questions 


\section{Group members' questions shape participation in health counselling and health education}

\section{Introduction}

Participation, empowerment and agency are key processes that support successful health promotion $[1,2,3,4,5]$. Health outcomes are better achieved when service recipients have a sense of autonomy and control in pursuing the goals of health-promoting activities $[5,6,7]$.

Street et al. [1] suggest that health outcomes are achieved through proximal outcomes in interaction, such as an increase in knowledge, shared understanding of the problem, social support, and stronger therapeutic alliance [1]. These proximal outcomes are realised through participation in interaction. In order to understand what promotes participation and what kind of participation is beneficial for reaching the proximal outcomes, we need research on the dynamics of interaction.

In this study we examine members' possibilities to participate in two group contexts of health promotion: health counselling for adults at risk of Type 2 diabetes, and health education in secondary school. Both environments share an institutional task wherein the leader - either a teacher or a counsellor - encourages the group towards a common goal of healthier behaviour through actions such as giving information and advice and prompting participants to reflect on whether they are currently leading a healthy lifestyle. Our focus is on the ways group participation is realised in the two environments.

Health counselling and health education are commonly conducted in group settings. Interaction in health counselling has mainly been studied in dyadic settings [however, see 8,9], and these studies have mainly concentrated on counsellors' actions - questioning, advice-giving and confrontation $[10,11,12,13,14]$. Less is known about clients' actions and counselling processes in group settings. Interaction in health education has not been studied, as research on classroom interaction has focused on the teaching of languages and theoretical subjects $[15,16,17]$. Both health education and health counselling attempt to influence individuals' attitudes and behaviour. Thus it is essential to gain information on clients' and students' possibilities to participate in efforts to achieve the institutional goals.

In institutional contexts, participants orient to the structures and norms of interaction that offer different kinds of opportunities for participation depending on their social role. Whether the situation is dyadic or multiparty, a recurrent feature is that the discussion is primarily driven by the professional $[18,19,20]$. This is easily observable in classroom interaction, where teachers regulate next-speaker selection, ask known-information questions and evaluate the answers they receive $[21,22,23,24]$. Leader-driven practice entails the regulation of participation in order to accomplish the institutional task at hand.

Members' initiatives are one key point for analysis of whether and how group members take an active role in group participation. Asking a question is a powerful device for steering the direction of conversation. It makes an answer relevant and thus cannot easily be bypassed. With a question, a participant can initiate both a new topic of talk and a new line of action, and reshape the participatory roles of the encounter $[25,26,27,8,28]$.

Students' initiative actions have been examined in academic counselling and classroom interaction, particularly from the perspective of how questions are treated as requests for advice, thus working for the institutional task $[29,30]$, or as attempts to challenge the advice or institutional agenda $[31,32,33]$. In classroom interaction, students can initiate topics and actions and display knowledge through questions. These initiations may, however, be treated as initiating a shift from the current institutional activity, and thus as transgressions [34,29,32]. 
In dyadic counselling, clients' questions can generate departures from counsellor-driven activities: by asking a question, a client is able to temporarily reverse the roles of questioner-answerer and speaker-listener. This can be accomplished either by the counsellor offering "question time" to the client or by the client initiating a question voluntarily. Offering "question time" sustains the counsellor's primacy and control over the discussion, and voluntary questions are suggested to be more significant breaches of the counsellor-driven procedure. [35] In group counselling interaction, "what about" types of question have been shown to function as seeking information or instruction [8]. So far there is no further research on other types of question or questions addressed to other group members.

In this article we explore patterns of group participation in the contexts of health education and health counselling. Our aim is to find out how group members' questions operate in shaping participation $[36,20]$. We show how with questions members can 1) request counselling, 2) engage in activities that resemble the leader's activities and thus "do counselling" for the other members, and 3) challenge what has been stated in the previous turns or counselling materials. Our focus on group interaction enables us to observe the dynamics of interaction between group members and its potential benefits with regard to the institutional task of supporting behaviour change.

\section{Material and methods}

\subsection{Data and participants}

The data consist of audiovisual recordings of three hours of health education lessons in secondary school (three groups, one lesson each) and 18 hours of health counselling sessions for adults with a high risk of Type 2 diabetes (six groups, one to three sessions each). The health education data were gathered from an intervention that aimed to increase physical activity and reduce sedentary behaviour in adolescents. Health education teachers delivered the intervention to groups of 14-21 students aged 14-15 years old over the course of three lessons [37]. The health counselling data were gathered from an intervention that aimed to increase physical activity, eating control and nutritional quality for adults. Groups of six to nine participants, led by nutritionists, met six times [38]. Informed consent was obtained from all participants, and the data were anonymised and transcribed. The study was approved by the ethics committee of the Tampere region and the Coordinating Ethics Committee of the Hospital District of Helsinki and Uusimaa (document number 50/E0/2007).

\subsection{Method}

In the preliminary phase of the analysis, we gathered all question-answer sequences in the data $(n=977)$, and compared the number of group leaders'1 and members' questions in each session. We focused on members' questions ( $n=330$ ), and excluded 83 questions that were oriented to the organisation of an ongoing assignment such as "Whose turn it is now?" or questions such as "What is in that picture?" Hence a detailed analysis was carried out of 247 members' question sequences that addressed the themes of the counselling interventions. The method applied was conversation analysis, a systematic method for analysing patterns of interaction based on ethnomethodological theory $[39,40,41,19,42]$. We analysed the sequential location of the question within the conversation and its allocation, that is, to whom the speaker was directing the question and who (if not the whole group) was thus being treated as the primary respondent [25]. Other aspects analysed were the design of the turns, the topical focus of the questions, who responded to the question, and the kinds of action embodied in the answer. We also paid attention to what happened after the response.

\section{Results}

\footnotetext{
1 "Leader" and "member" are used to refer to participants in both environments. They include the teacher and counsellor, and the students and clients, respectively.
} 
In general, both environments were leader-driven: leaders followed the intervention agenda, initiated and instructed on assignments, delivered information, and took general responsibility for the timing and content of sessions. Asking questions was a salient counselling activity, and teachers and counsellors used similar question types: 1 ) questions that asked members to recall facts: "What are the benefits of physical activity?", 2) questions that invited members to reflect: "What do you think about...?", or 3) survey questions: "How many of you live near here?" In the health counselling groups, it was common for clients to answer the counsellor's questions in "rounds", one client at a time, in the order in which they were seated around the table, whereas in health education lessons, the students volunteered to answer questions that were allocated to the whole group. In both environments, leaders also allocated some of the questions to specific respondents.

A well-known pattern of interaction - the IRE/F structure - was common in both environments. The IRE/F structure unfolds as initiation from the leader, response from the member, and evaluation or feedback from the leader [43,44]. Table 1 shows examples of IRE/F in both contexts.

\section{[[insert Table 1 around here (tables and captions are provided at the end of this document)]]}

Initiation is observable in both data excerpts: the group leaders ask a question (lines A3-6 and B12) and allocate the next speaker (A8, B4-5]. A response is given by the student and the client (A911, B6-10, B12-13). Thereafter, the leaders give feedback: the teacher gives a formulation of the answer as feedback to the student (A12-13); the counsellor highlights some details of Maija's answer by writing them on the flip chart (B11) and then verbally evaluates a part of the answer as important (B14-15). The IRE/F structure illustrates a leader-driven practice where group leaders control the flow of discussion through allocated questions and by highlighting the institutionally relevant parts of the answers through evaluations and formulations.

Leaders' questions were frequent in both environments. Members' questions were considerably more frequent in health counselling sessions than in health education lessons (Figures 1 and 2). However, there were notable differences in the number of members' questions between different health counselling groups, and between sessions of the same group (Figure 3). The question topics varied from whether some specific food was recommended to enquiries about group members' personal lives.

\section{[[insert Figures 1, 2, and 3 near here]]}

Drawing upon the analysis of sequential location, turn allocation, turn design and topical focus, and of actions embodied in the responses to the questions, we found three types of function which members' questions served: requesting counselling, doing counselling and challenging a particular topic. While members' questions were significantly more frequent in health counselling than in health education, all three types of function were found in both data sets.

Table 2 illustrates the relation of the sequential location of members' questions to the function of the question, and the distribution of first responses between the leader and the members. First, questions that initiated a new sequence were either requests for counselling or challenges to $a$ particular topic. In addition, they were doing counselling when they were allocated to another member. Second, questions that were located after information or advice were challenging it or requesting counselling. Third, questions that followed another member's disclosure were challenging it or doing counselling. In the following, we describe how questions generate shifts in participatory roles, and how this offers possibilities for member-driven discussion. There were also 32 questions that were interpreted as transitions outside the current action or topic. These are not included in Table 2 and will be addressed in section 3.4. 


\section{[[insert Table 2 near here]]}

\subsection{Member's question is a request for counselling}

Ninety-five members' questions (Table 2) functioned as requests for advice or information about the counselling topics (for example, nutritional recommendations), or for confirmation of some knowledge the speaker claimed to already possess. They mainly followed information or advice, or initiated a new sequence. The latter were direct questions referring to a topic that had been previously discussed or was assumed to be known by the participants. The questions positioned either the leader or another member as a respondent, and thus accomplished a temporary change in the leader-driven trajectory of discussion. By answering the question and providing the requested information, the respondent accepted the offered position as the expert.

\section{[[insert Table 3 near here]]}

In Table 3 there are two member's questions that request counselling. The first (11-12), by Sonja, is marked as a breach of the current activity with the words "by the way". It returns to a topic that was discussed earlier: weighing the participants. The question offers a choice of two possibilities, of which the counsellor confirms (13) the second. This evokes a follow-up question from Merja to other group members, who are her co-workers, on whether they should weigh themselves in their workplace (17-18). Paula asks yet another question (21-22), taking up a new topic concerning the pedometers that the counsellor is simultaneously handing out to the members (27-29). Paula asks about the proper number of steps to be taken. By asking for recommendations she explicitly marks the nutritionist as the knowledgeable person. Further, by asking for information, Paula orients to the institutional task at hand, showing interest in the goal of the group.

Sonja's and Paula's questions show how, by asking a question, participants can initiate a topic and position the group leader as a respondent while maintaining the leader's position as an expert. Sonja asks the first question as the counsellor is commencing a new activity, and manages to temporarily return to a preceding topic. Paula's question steers the discussion back from a multiparty discussion between group members to a dialogue between a group member and the counsellor. The questions initiate shifts in participatory roles and topics, and the participants treat them as relevant and accept the offered roles.

\section{[[insert Table 4 near here]]}

In Table 4, the teacher has asked what kind of harm is caused by extensive screen time, and one student has already answered that it is harmful to the eyes (data not shown). The teacher solicits more responses and allocates the turn to Asko (3). Instead of responding to the teacher's question, Asko asks a question about whether the classroom projector lamp is harmful to the eyes (4-5). Thus the question disaligns from the line of activity suggested by the teacher and returns to a previously discussed topic. While the participatory roles in the current IRE/F framework position the students as respondents, by asking a question Asko shifts the role of respondent to the teacher while sustaining the teacher's role as an expert. Although the question is allocated to the teacher, another student, Jake, answers it first (6-7), volunteering his existing knowledge. Thereafter the teacher responds by giving information. It is noteworthy that the teacher brings up a different explanation from Jake's, emphasising the blinking of the lights rather than the darkness of the room as the reason for the strain on the eyes. As Jake repeats his own explanation of the problem (12), the teacher confirms this too. By answering the question and delivering the requested information the teacher accepts the offered participatory role as a respondent. By giving a different explanation for the strain from Jake's, and by confirming Jake's comment on the darkness of the room (13), she also makes a move to regain her position as the expert.

These examples illustrate how group members request counselling by asking questions concerning the topic that is currently being or has earlier been talked about. In both examples, the 
questions were somewhat disaligning from the current activity suggested by the leader. However, both showed an orientation towards the institutional task. By requesting counselling, the members offered the expert position either to the leader or to the other participants. In this way they managed to steer the direction (both topic and activity) of the counselling discussion.

\subsection{Member's question is doing counselling}

Sixty-eight of the members' questions (Table 2) requested information about the respondent's personal situation or actions, offered advice or new perspectives, or invited the respondents to evaluate some topic of talk. With these questions the members were adopting tasks that were usually performed by the leader. They were mostly located after another member's disclosure or initiated a new sequence. They were usually designed with an explicit turn allocation or a contextual reference that implied turn allocation to a specific respondent or to a group of respondents. They were always answered by one or more group members, never by the leader. The questions changed the leader-driven trajectory of discussion so that the leader was set aside as a listener. Table 5 is a case in point from the health counselling data.

The episode is launched with a written assignment and the leader's instruction to members to assess their own habits and potential need for improvement. The counsellor-driven initiation of an assignment is observable in lines $1-5,7$ and 12. The first member's question (16) is located after group member Maria's disclosure. This would be a relevant place for the counsellor to give feedback (as illustrated in Table 1), provide information or advice, or ask a follow-up question. Instead, another member, Sonja, asks a question.

\section{[[insert Table 5 around here]]}

The question (16) is oriented to the institutional task of achieving change. It suggests that Maria has been actively involved in contemplating possible solutions to her problem. In her answer, Maria describes how she has tried to solve her problem (starting at line 19); the leader subsequently acknowledges Maria's answer (24). As Maria's disclosure continues, Sonja asks another question (29-30), that offers one possible solution - a preferred habit - and can thus be interpreted as advice. Maria accounts why she is not doing as suggested $(31,33)$ - a typical way of rejecting advice - and continues by suggesting another solution (35-36). It is noteworthy that although Maria resists Sonja's advice, her own solution is also in line with the institutional task. The leader gives minimal acknowledgements and lets the members' discussion continue.

As illustrated in this example, this kind of members' question was located where the leader's follow-up questions, evaluations or advice could have taken place. They were designed similarly to the ways in which the leader's questions were designed and aligned with the institutional task. Thus the members adopted the role of counsellor, asking about personal solutions and giving advice in the form of a question. As such they were "doing counselling", resulting in member-driven participation.

\subsection{Member's question is challenging the previous talk}

Forty-eight questions (Table 2) called into question some aspect of the previous talk or of the materials used in the intervention. They were mostly located after another member's disclosure or information or advice, and they were allocated either to one or more group members or to the leader. They were often designed with a clitic $-\mathrm{kO}^{2}$ or the word "eikö" (isn't), which indicate doubt by requesting confirmation while implying that the opposite is anticipated $[45,46,47]$.

\footnotetext{
2 For example: "PitääkÖ juoda maitoa?" - "Does one need to drink milk?”; “LaihtuukO tällä?" - "Does one lose weight with this (diet)?"
} 
Table 6 illustrates a challenging question to a group member. The question (21) refers to the meal the group members (who are colleagues) have had for lunch.

\section{[[insert Table 6 around here]]}

At the beginning of the episode, Paula reveals that she has made a deal with her colleague to stop her from bingeing. At lines 9-10 Ella initiates a challenging remark about whether the food was really that delicious, but this remark does not get a response. With a question (21) Ella manages to topicalise the tastelessness of the meal in question. The topic is known to the participants including Ella herself, so this question is not asking for information about the food. The participants interpret Ella's enquiry about the taste of the meal as a critique of overeating even when the food is not delicious, and this generates multiparty discussion among members. Paula responds with a confirmation and an account $(22,25)$, and Merja and Maria also join the conversation with their responses $(23,26)$. Furthermore, the clients continue $(27,28,33,35)$ and ridicule the habit of overeating.

Table 7 is an example of a challenging question to the group counsellor. The question (6) is located after counsellor's information about vegetables. It picks one item from the list of beneficial food items, and by requesting confirmation that this item is not fattening, it challenges the counsellor's previous turn.

\section{[[insert Table 7 around here]]}

The participants treat the question as challenging: there is a significant gap after the question (7) and another client explicitly describes the turn as "throwing out" (9). However, the counsellor treats it as a relevant question, and answers it. Furthermore, the counsellor provides an interpretation of the question (16) and evidence for the answer (19-21). Thus, while retaining her expert position and resisting the perspective indicated in the question that bananas might be fattening, the counsellor also accepts the position of respondent (as with the types of question that request counselling). Thus the counsellor acknowledges the topic of the question as relevant and the action of challenging as legitimate.

While the challenging questions cast doubt on a particular topic of talk, in both examples they were aligning with the institutional task with regard to healthier lifestyles. In the first example, the question did not induce a shift in participatory roles: the discussion was already member-driven. Nevertheless, it sustained the member-driven discussion while introducing a new perspective, and generated multiparty discussion. In the second example, the question induced a temporary shift towards member-centred discussion, similarly as questions that requested counselling from the leader.

\subsection{Member's question is treated as deviation}

In general, participants treated members' questions as relevant actions in which members of a group counselling intervention could legitimately engage. This was observable in how the members accepted the changes in participatory roles. However, in 32 cases participants did not treat the question as a relevant action and sought to sustain their current participatory roles.

In the next excerpt from the health education lesson (Table 8), the teacher offers "question time" [35] to a student. Therefore there is an opportunity to shift towards member-driven discussion, for example by asking for information from the teacher. However, instead of answering the question, the teacher immediately blocks it with a counter-question, thus treating it as a disruption.

\section{[[insert Table 8 around here]]}


It is uncertain whether the question (2) is intended as heckling or is rather a real issue the boys want to discuss. The teacher seems to interpret the question as heckling and responds to it with a counter-question, using a rather annoyed tone of voice (4). We can see how Elias answers the question with an open-class repair initiation - "huh" (7) - thus treating the counter-question as unexpected.

The teacher treats Elias's answer as if it indicates a problem with hearing (8), and repeats her counter-question. Next, another student joins in with information that could be interpreted as an account of Elias's question $(9,11,13-14)$. The teacher ignores his turn and states that the answer is obvious, implying that the question was inappropriate (12). The teacher then moves on (16-18), reinforcing her treatment of the question as inappropriate and a disruption, even though she had initially offered "question time" to the student.

In the 32 cases of the data, the leader or the members treated the questions as transitions away from the current action or as topically inappropriate. We could not identify any topic or sequential location as categorically "non-relevant". Thus we suggest that the participants monitor whether the questions align with the institutional task and agenda, and make their interpretations depending on local contingencies.

\section{Discussion and Conclusion}

\subsection{Discussion}

In many respects, group members' questions operate similarly in both health counselling and health education. First, they have similar sequential locations. Second, they have similar functions: 1 ) requesting counselling, 2) doing counselling, 3) challenging. Third, they induce a shift in participatory roles.

In light of the current analysis, members' questions can be seen to support behaviour change in various ways [1]:

1) Requests for counselling ask for advice and information on specific topics, thus increasing knowledge of the issues that are relevant for the participants. This helps leaders to adjust the counselling to better serve the needs of the participants, which strengthens the therapeutic alliance.

2) Doing counselling may induce an increase in knowledge, but it is noteworthy that other group members may give advice or feedback to each other that is not accurate regarding the institutional goals.

3) Challenging questions may lead to discussions where the leader can correct misunderstandings or false presuppositions. This can result in an increase in knowledge. When the leader treats challenging questions as legitimate actions, thereby showing respect for the views of the participants, this may lead to a stronger therapeutic alliance.

Regardless of the function of the question, members' questions make members' views and experiences available to the group, providing material for the members to reflect upon, recognise and use to give social support.

\subsection{Conclusion}

Members' questions shape the participatory roles in health education and group counselling to allow member-driven interaction. Questions are used to topicalise issues relevant to the members and thus constitute a way to steer the direction of the discussion. Members' questions can steer the discussion from dyadic discussion with the leader, to dyadic or multiparty discussion among the 
group members, and back again. Thus group members' questions constitute a pivot point in participation.

Requesting counselling and challenging the issues that are dealt with in the counselling discussions are activities that are possible in dyadic counselling, and they have been recognised in previous research $[30,31,35]$. The group context makes more complex participation available. For group members, asking a question provides a legitimate way to influence the dynamics of counselling interaction. For group leaders, members' questions afford an observation point from which to monitor, facilitate or restrict member participation in the counselling session.

\subsection{Practice implications}

Observing the occurrence of group members' questions helps group counsellors and health educators to adjust their own actions accordingly and thus facilitate or guide group participation. Comparison of the type and frequency of members' questions is a way to detect different trajectories for delivering group interventions, and can thus be used to develop methods for process evaluation of interventions.

Funding: Data collection (including video recordings in the Elvira Counselling Study) was supported by the Academy of Finland (grant number 118176); the Finnish Institute of Occupational Health; and the Emil Aaltonen Foundation. Research was supported by the School of Social Sciences and Humanities, University of Tampere; the Science Foundation of the City of Tampere; the Juho Vainio Foundation; the Emil Aaltonen Foundation; and the Strategic Research Council at the Academy of Finland (grant number 303430).

All authors confirm all personal identifiers have been removed or disguised so the persons described are not identifiable and cannot be identified through the details of the story. 
Appendix: Transcription symbols

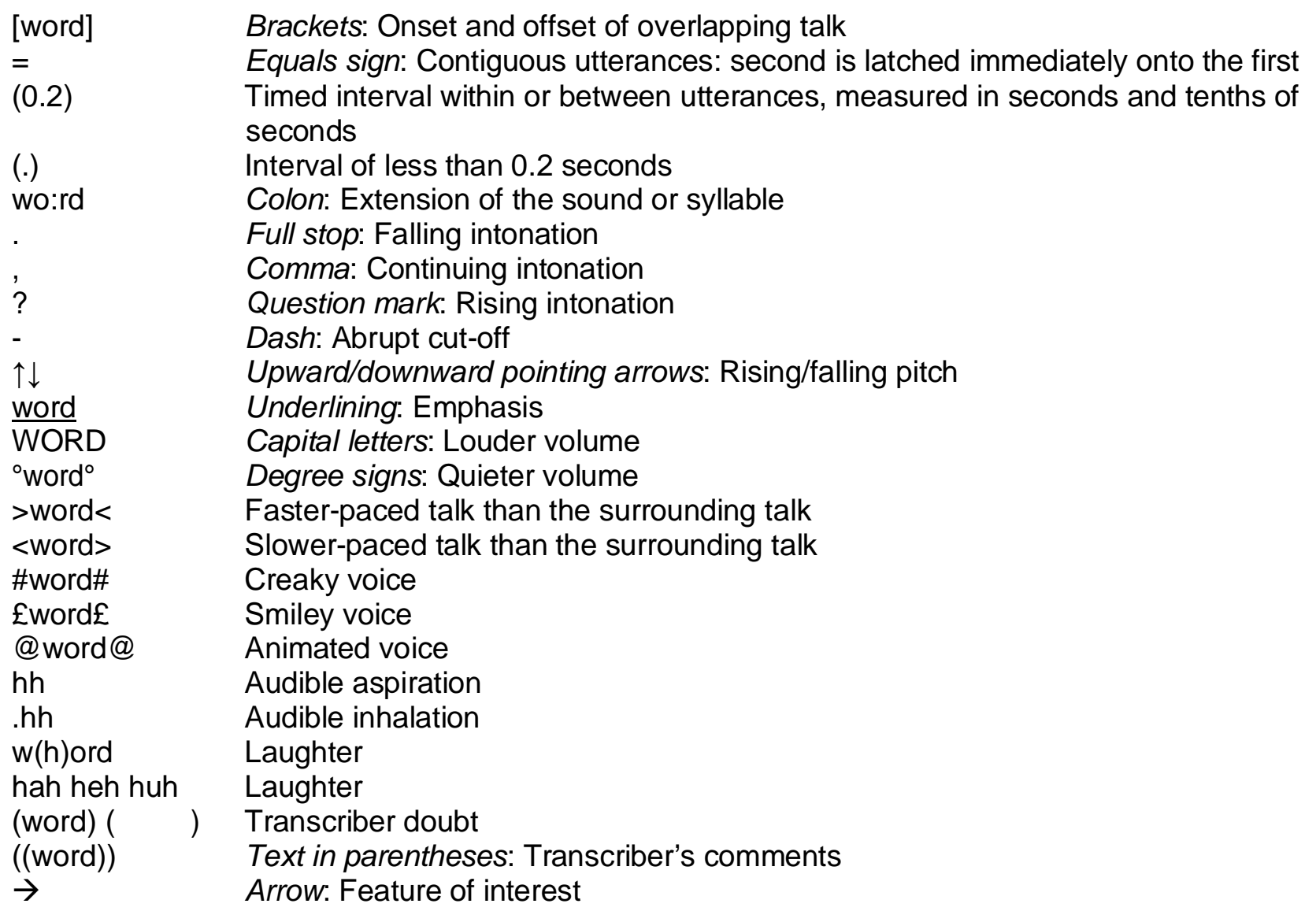




\section{References}

[1] R.L. Street, G. Makoul, N.K. Arora, R.M. Epstein, How does communication heal? Pathways linking clinician-patient communication to health outcomes, Patient Educ Couns 74 (2009) 295 301.

[2] N. Wallerstein, What is the evidence on effectiveness of empowerment to improve health? Health Evidence Network report, WHO Regional Office for Europe, Copenhagen, 2006, http://www.euro.who.int/Document/E88086.pdf

[3] S. Brandstetter, J. Rüter, J. Curbach, J. Loss, A systematic review on empowerment for healthy nutrition in health promotion. Public health nutrition 18 (2015), 3146-54.

[4] M. Sharma, Theoretical foundations of health education and health promotion, Jones \& Bartlett Publishers, 2016.

[5] R.M. Ryan, E.L. Deci, Self-determination theory and the facilitation of intrinsic motivation, social development, and well-being, Am Psychol 1 (2000) 68-78.

[6] A. Bandura, Self-Efficacy: The Exercise of Control. Freeman, New York 1997.

[7] A. Bandura, 'Health promotion by social cognitive means', Health Education \& Behavior 31

(2004) 143-64.

[8] A. Fasulo, J. Zinken, K. Zinken, Asking 'what about' questions in chronic illness self-

management meetings, Patient Educ Couns 99 (2016) 917-25.

[9] S. Wiggins, Managing blame in NHS weight management treatment: Psychologizing weight and 'obesity', Journal of Community \& Applied Social Psychology 19 (2009) 374-87.

[10] S. Sarangi, "The Spatial and Temporal Dimensions of Reflective Questions in Genetic Counselling", In Why Do You Ask? The Function of Questions in Institutional Discourse (Alice F. Freed, Susan Ehrlich, eds.), Oxford, Oxford University Press, (2009) pp. 235-55.

[11] T. Strong, D. Zeman, Dialogic Considerations of Confrontation as a Counseling Activity: An

Examination of Allen Ivey's Use of Confronting as a Microskill, Journal of Counseling and

Development 88 (2010) 332-9.

[12] M. Poskiparta, L. Liimatainen, T. Kettunen, P. Karhila, From Nurse-Centered Health Counseling to Empowermental Health Counseling, Patient Educ Couns 45 (2001) 69-79.

[13] M. Poskiparta, T. Kettunen, L. Liimatainen, "Reflective Questions in Health Counseling", Qualitative Health Research, 8 (1998) 682-93.

[14] Gale Miller, David Silverman, (1995), Troubles Talk and Counselling Discourse: A

Comparative Study, Sociological Quarterly, 36 (1995) 725-47.

[15] T. Koschmann, J. Mori, "It's Understandable Enough, Right?" The Natural Accountability of a Mathematics Lesson, Mind, Culture \& Activity, 23 (2016) 65-91.

[16] F. Rusk, M. Pörn, F. Sahlström, (2016), The management of dynamic epistemic relationships regarding second language knowledge in second language education: Epistemic discrepancies

and epistemic (im)balance, Classroom Discourse 7 (2016) 184-205.

[17] V. Heller, Meanings at hand: Coordinating semiotic resources in explaining mathematical terms in classroom discourse, Classroom Discourse

[18] P. Drew, J. Heritage, Talk at work: Interaction in institutional settings, Cambridge University Press, Cambridge 1992.

[19] S. Hester, D. J. Francis, "Is institutional talk a phenomenon? Reflections on ethnomethodology and applied conversation analysis", in: A. McHoul, M. Rapley (Eds.), How to Analyse Talk in Institutional Settings: A Casebook of Methods London, Continuum, 2001, pp. 206-17

[20] P. Drew, 2003. "Comparative analysis of talk-in-interaction in different institutional settings: A sketch". In: Studies in language and social interaction: In honor of Robert Hopper, Edited by: Glenn, P., LeBaron, C. D. and Mandelbaum, Mahwah, NJ: Erlbaum, pp. 293-308.

[21] A. McHoul, The organization of turns at formal talk in the classroom, Language in Society 7 (1978) 183-213.

[22] H. Mehan, 'What time is it, Denise?' Asking known information questions in classroom discourse, Theory into Practice 18 (1978) 285-94.

[23] G. H. Lerner, Turn design and the organization of participation in instructional activities, Discourse Processes 19 (1995) 111-31.

[24] R. Jones, J. Thornborrow, (2004), Floors, Talk and the Organization of Classroom Activities, Language in Society 33 (2004) 399-423. 
[25] H. Sacks, E.A. Schegloff, G. Jefferson, A simplest systematics for the organization of turntaking for conversation, Language 4 (1974) 696-735.

[26] E.A. Schegloff, On some questions and ambiguities in conversation, in: J.M. Atkinson, J. Heritage (Eds.), Structures of Social Action: Studies in Conversation Analysis, Cambridge University Press, Cambridge, 1984, pp. 28-52.

[27] C.E. Ford, Questioning in meetings: Participation and positioning, in: A. F. Freed, S. Ehrlich (Eds.), Why Do You Ask: The Function of Questions in Institutional Discourse, Oxford University Press, Oxford, 2009, pp. 211-34.

[28] S. Ehrlich, A.F. Freed, The function of questions in institutional discourse: An introduction, in: A.F. Freed, S. Ehrlich (Eds.), Why Do You Ask? The Function of Questions in Institutional Discourse, Oxford University Press, Oxford (2009), pp. 3-19.

[29] O. St. John, J. Cromdal, Crafting instructions collaboratively: Student questions and dual addressivity in classroom task instructions, Discourse Processes 4 (2016) 252-79.

[30] S. Vehviläinen, Student-initiated advice in academic supervision, Research on Language and Social Interaction 2 (2009) 143-90.

[31] S. Vehviläinen, Problems in the research problem: Criticism and resistance in academic supervision encounters, Scandinavian Journal of Educational Research 2 (2009) 185-201.

[32] M.S. Solem, Displaying knowledge through interrogatives in student-initiated sequences, Classroom Discourse 1 (2016) 18-35.

[33] S. Garton, Speaking out of turn? Taking the initiative in teacher-fronted classroom interaction, Classroom Discourse 1 (2012) 29-45.

[34] H.Z. Waring, E. Reddington, N. Tadic, Responding artfully to student-initiated departures in the adult ESL classroom, Linguistics and Education 33 (2016) 28-39.

[35] A. Peräkylä, D. Silverman, Reinterpreting speech-exchange systems: Communication formats in AIDS counselling, Sociology 4 (1991) 627-51.

[36] S. Speer Hypothetical Questions: A Comparative Analysis and Implications for "Applied" vs. "Basic" Conversation Analysis, Research on Language and Social Interaction 45 (2012).

[37] A.M. Jussila, T. Vasankari, O. Paronen, H. Sievänen, K. Tokola, H. Vähä-Ypyä, A. Broberg, M. Aittasalo, KIDS OUT! Protocol of a brief school-based intervention to promote physical activity and to reduce screen time in a sub-cohort of Finnish eighth graders, BMC Public Health 15 (2015) 1-9. [38] J. Laitinen, E. Korkiakangas, M. Alahuhta, S. Keinänen-Kiukaanniemi, U. Rajala, O. Timonen, T. Jokelainen, A.-M. Keränen, J. Remes, A. Ruokonen, P. Hedberg, A. Taanila, P. Husman, S.

Olkkonen, Feasibility of videoconferencing in lifestyle group counselling, Int $\mathrm{J}$ Circumpolar Health 5 (2010) 500-11.

[39] J. Heritage, Garfinkel and Ethnomethodology, Polity Press, London, 1984.

[40] C. Antaki, Six Kinds of Applied Conversation Analysis, in: C. Antaki (Ed.), Applied

Conversation Analysis. Intervention and Change in Institutional Talk, Palgrave Macmillan,

Basingstoke, 2005 pp.1-14.

[41] C. E. Ford, "Conversation analysis and turn taking", in: C. A. Chapelle (Ed.), The Encyclopedia of Applied Linguistics, Oxford, U.K., Wiley-Blackwell, 2013, pp. 1121-7.

[42] P. ten Have, "Applied conversation analysis", in: A.McHoul, M. Rapley (Eds.), How to Analyse

Talk in Institutional Settings: A Casebook of Methods, London, Continuum, 2001, pp. 3-11.

[43] J.McH. Sinclair, R.M. Coulthard, Towards an analysis of discourse: The English used by

teachers and pupils, Oxford University Press, London, 1975.

[44] T. Koole, Classroom interaction, in: K. Tracy, C. Ilie, T. Sandel (Eds.), International

Encyclopedia of Language and Social Interaction, Wiley-Blackwell, Oxford, 2015.

[45] A. Hakulinen, M. Vilkuna, R. Korhonen, V. Koivisto, T.R. Heinonen, I. Alho, (Eds.), Iso suomen kielioppi [Great Finnish grammar], Suomalaisen Kirjallisuuden Seuran toimituksia 950. Helsinki: Suomalaisen Kirjallisuuden Seura, 2004.

[46] L. Raevaara, Kysyminen toimintana. Kysymys-vastaus-vieruspareista arkikeskustelussa

[Asking as an action. Of question-answer -sequences in everyday conversations], University of Helsinki, Helsinki, 1993.

[47] V. Yli-Vakkuri, Suomen kieliopillisten muotojen toissijainen käyttö [Secondary use of the grammatical forms of Finnish language], TYSYKLJ 28, University of Turku, Turku, 1986. 
[48] D. Maynard, J. Freese, Good news, bad news, and affect: Practical and temporal "emotion work" in everyday life, in: A. Peräkylä, M.-L. Sorjonen (Eds.), Emotion in Interaction, Oxford University Press, Oxford, 2012, pp. 92-112. 


\section{Table 1}

A) HE2/II: IRE/F in health education
A1 T: mut jos AJATELLAAN ettei käydäkään but if THINK+PASS that+not go+not but if WE THINK that we won't go
A2 o:hjatussa, liikunnassa?
instructed, sport?
to o:rganized, sports?
A3
(.) niin, (1.0) miten sä silloin
(.) so, (1.0) how you then
(.) so, (1.0) how could you then

A4 voisit semmosilla pienillä

could sometwith smalltwith

with some little

A5 jutuilla lisätä sitä sun things+with increase that your things increase your

A6 arkiliikkumistasi. everyday+moving. everyday physical activity.
A 7
$(2.2)$

A8 T: ää Jelena.

A9 J: no $\uparrow$ jos nyt kävelee kouluun well $\uparrow$ if now $0+$ walks schooltto well $\uparrow$ if one walks to school

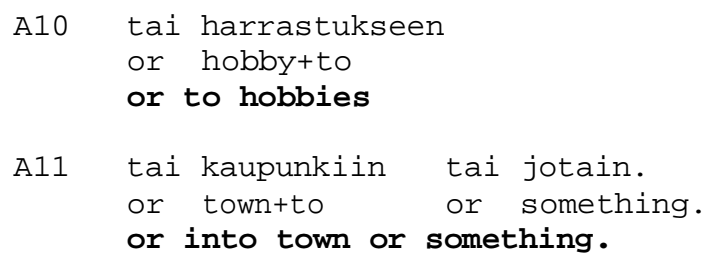

A13 1 SIT ̈̈ $\uparrow$ KÄVELYN määrää.

$\uparrow \mathrm{THAT} \uparrow$ WALKING amount.

$\uparrow$ THE $\uparrow$ AMOUNT of walking.
B) $H C 7 / I$ : IRE/F in health counselling

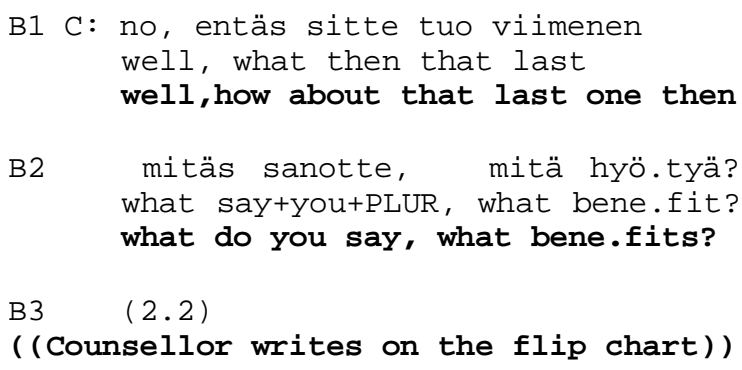

B8 ja >tietenki< terveys and $>$ oftcourse $<$ health and >of course< health

B9 ynnä muut asiat, plus other things, and other things,

B10 (täs niin on) hyötyjä? (here then are) benefits? (here so they) are benefits?

B11 (1.2)

((Counsellor writes on the flip chart))

B12 M: virkeämpi niinku tö:issä alert+more like work+at One would be more alert at wo:rk

B13 ois sitten kanssa.

$0+$ betwould then also. then also.

B14 C: joo tuo on tärkee näkökohta yeah that is important aspect yeah that is an important aspect

B15 tuo virkeys.

that alertness.

that alertness.

B16 M: mhm

$B 17 \quad(0.2)$ 


\section{Table2}

Sequential location and function of members' questions, and distribution of responses between leaders and members in health counselling and health education

\begin{tabular}{|l|r|r|r|r|r|r|}
\hline & \multicolumn{2}{|c|}{$\begin{array}{c}\text { Requesting } \\
\text { counselling }\end{array}$} & \multicolumn{2}{c|}{ Doingcounselling } & \multicolumn{2}{c|}{ Challenging } \\
\hline Sequential location & Leader & M ember & Leader & M ember & Leader & Member \\
\hline Initiative & 37 & 11 & 0 & 25 & 4 & 7 \\
\hline After information or advice & 30 & 8 & 0 & 2 & 15 & 0 \\
\hline $\begin{array}{l}\text { After another member's } \\
\text { disclosure }\end{array}$ & 3 & 3 & 0 & 41 & 0 & 22 \\
\hline Within own disclosure & 2 & 1 & 0 & 0 & 0 & 0 \\
\hline & 72 & 23 & 0 & 68 & 19 & 29 \\
\hline
\end{tabular}




\section{Table3.}

HC5/I: Member's question is a request for counselling

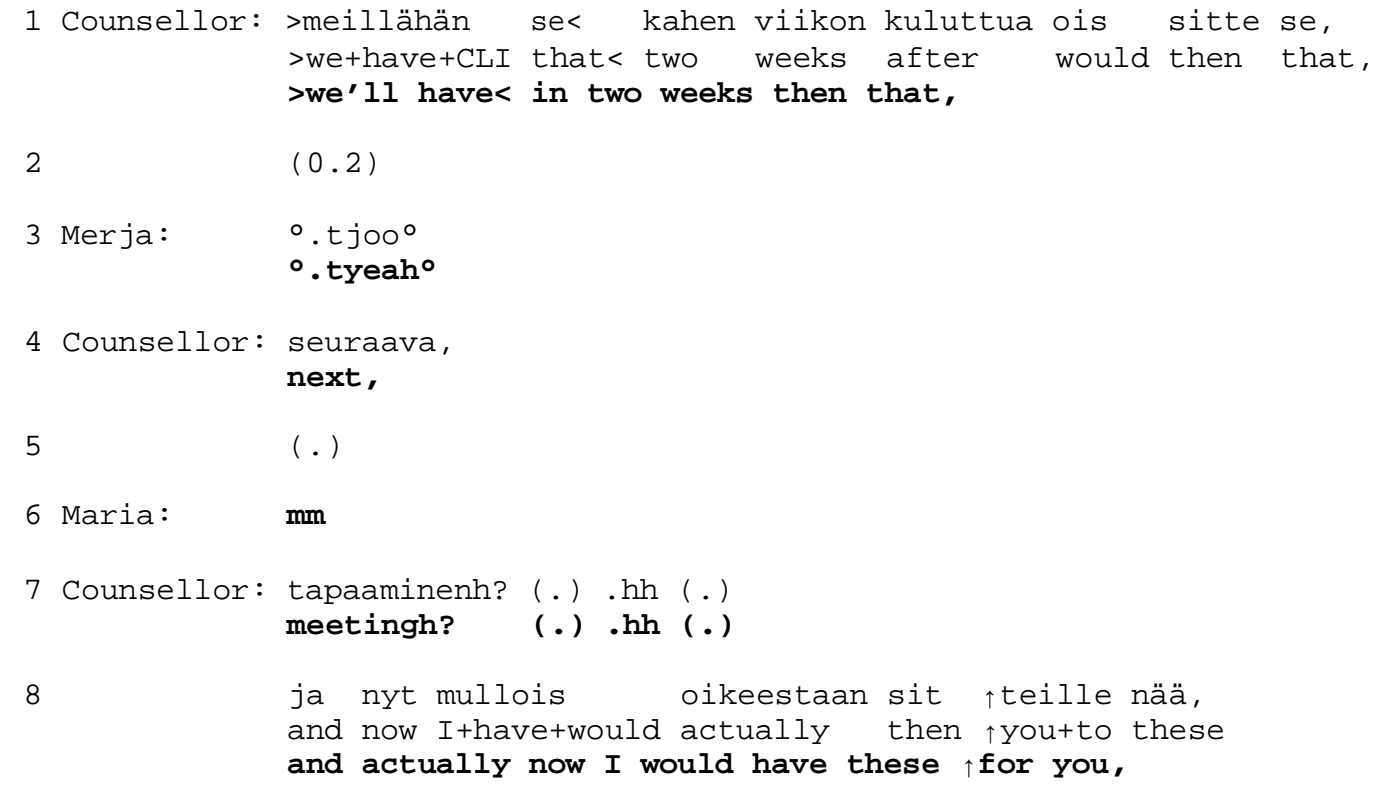

11 Sonja: [oliko mute ] jatus et joka kerta on se punnitus [wastQ by+the+way ] idea that every time is that weighing [by the way was the]idea that we would weigh ourselves every time

16 Sonja:

[ joo.

[yes.

17 Merja:

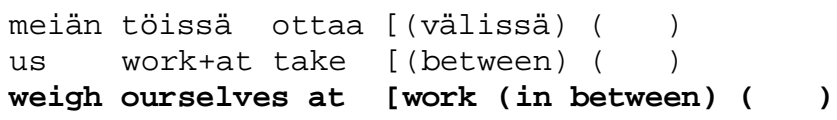

19 Maria:

[pitää.

[must.

[yes we do. 
mitää suositusta kuinka paljo askelia pitäs †tulla?

any recommendation how much steps should $\uparrow$ come?

any recommendation for how many steps one should $\uparrow$ take

24 Counsellor: .hh (.) no sehä on se to\#ta se\#, (.)

.hh (.) well it+CLI is that er\#m that\#, (.)

.hh (.) well it is that er\#m, that\#, (.)

mm \#ee ö ee\# m, >sanotaanko et jos me aatellaan se<

$\mathrm{mm}$ \# ee ö ee\# $\mathrm{m}$, >let's+say that if we think that<

$\mathrm{mm}$ \#ee ö ee\# $\mathrm{m}$, >let's say that if we think of it as<

terveysliikuntaa. niin ni sehän on:, se on, health+activity+about. then so it+CLI is:, it is, exercise for health. so then it is:, it is,

se on kymmenentuhatta askelta.

it is ten+thousand steps.

it is ten thousand steps.

on se niinku semmonen terveysliikunnan.

is that like that+kind health+activity+of.

that is the (recommendation) to exercise for health. 


\section{Table4.}

HE2/II: M ember's question is a request for counselling

1 Teacher: mitäs mula.

anything else.

2

$(0.6)$

3 Teacher:

äsken oli paljon käsiä ylhäällä.=Asko.

a+moment+ago were lot+of hands up. =Asko.

there were a lot of hands up a moment ago.=Asko

4 Asko: $\quad$ niin että rasittaakse silmiä jos kattoo tähän

so that strainstit eyes if $0+$ looks here+at

so does it strain eyes if one looks into this

5

valolamppuun (mikä) [( ) ( )

light+lamp+at (which) [ ( ) ( )

light bulb (which [() ()

6 Jake: [kyllä rasittaa.

[yes strains.

[yes it does.

7

>tää on niin pieni<, pi-pimee [huone?

$>$ this is such+a small<, da- dark [room?

>this is such a small<, da- dark [room?

8 Teacher:

$[\uparrow \mathrm{no}$,

[ $\uparrow$ well,

9

$\uparrow$ tämmöset $\uparrow v i l k k u v a t(0.8)$

$\uparrow$ these $\uparrow$ blinking $(0.8)$

hä- vilkkuvat valothan kyllä vähän voi rasittaa että,

di-blinking lights+CLI indeed a+little can strain so,

di-blinking lights can indeed cause some strain so,

ei toi oo oikeen, hyvä silmille pi[temmän päälle.

no that is really, good eyes+for lo[nger onttop.

it's not really, good for the eyes [in the long run.

12 Jake:

13 Teacher: niin. $(0.8)$

yes. $(0.8)$ [tää on noin pimeä huone nytten.

[this is so dark room now.

[this is such a dark room now. 


\section{Table5.}

HC5/III: Member's question to other member is "doing counselling"

1 Leader: on hyvä kattoo niitä missä menee $\downarrow$ hyvin

(.) ittis good to+check those where goestit

well

It is good to check those that go $\downarrow$ well (.)

2

ja sitte toinen oli se että millaisessa tilanteessa on parannettavaa and then another was it that what+kind+in stuation+in is improvement+need and then another was that in what kind of situation we could do better

ja (.) .mt millaiset tilanteet koette tuota (.) erityisen niinku and what+kind+of stuations experience+you like especially like and (.) .tch what kind of situations you feel like (.) especially like

riskialttiina ni (.) syömisen hallinnan suhteen.

risky like eatingtof controltof inttermstof

risky as (.) in terms of eating control.

5 Ella: $\quad \mathbf{m m}$

$6 \quad(1.2)$

7 Leader: mitä teille, tuliko teille?

what you+for, got $+Q$ you + for

What did you, did you?

8

$(1.4)$

9 Maria: mun, mun näitä positiivisia asioita on se et et mun ei m- öö, my, my these positive things is thetthing that that I not my, one of these positive things of mine is the thing that that I don't $m-$

tarvii enää paneutua siihen aamupalaan et mä syön säännöllisen, need+to anymore focus that+on breakfast that I eat regular umm, need to focus on that breakfast that I eat a regular,

ja terveellisen

and [healthy

and [healthy

12 Leader:

$[$ joo $=$

[Yeah=

13 Maria:

=aamupalan, breakfast

(.) ja mä syön lounaan säännöllisesti että mun ongelma on

=breakfast, and I eat lunch regularly so my problem is

sitte se pitkä iltapäivä ja se kotisyö[pöttely illalla.

then that long afternoon and that home+bi[ngeing night+at

then that long afternoon and that binge[ing at home at night.

15 Sonja:

$[\mathrm{mm}$,

16 Sonja: oot sää [keksiny nyt siihen jonku, mm, have youlfigured now that+for something,

Have you[figured out something for that now, mm,

17 Maria:

[siihen

[that+for

[for that

(.) 
19 Maria: no se hedelmien m- määrä ja niitten, niitten käyttö et mä syön, well that fruitrof amount and their, their use that I eat well that amount of fruit and their, their use is that I eat,

ehkä pari omenaa tai appelsiinia kun mä tuun töistä

maybe atcoupletof apples or oranges when I come worktfrom

maybe a couple of apples or oranges when I come from work

$21 \mathrm{XXX}: \quad \mathrm{mm}$

22 Maria: ja istun vähän aikaa alas ja luen lehteä tai muta että et sit vasta, and sit short while down and read magazine or other that that then not+until and sit down for a while and read a magazine or something so not until then,

(.)

24 Leader: $\quad \uparrow$ joo. ((nyökkää))

$\uparrow$ Yeah. ( (nods))

25 Maria:

ottaa [jonku

take+0 [some

one takes [some

26 Paula:

[mm [mm

27 Maria:

[voileivän ja kun siellä on jo se kylläsyyden tunne [sandwich and when there is already that fullnesstof sense [sandwich and when there is that sense of fullness already

olemassa nii kyl se kantaa sitte yllättävän pitkäl[le.

existing so indeed it carries then suprisingly [far

so it indeed carries on surprisingly

[far then.

29 Sonja:

$\rightarrow$

30

$\rightarrow$

lämpimän ruuan vielä kotona sit[te.

warm meal even hometat th[en

a warm meal even at home th [en.

[ laitakko nää

[Do you cook

31 Maria:

$\begin{array}{llll}{[\text { e:n }} & \text { (.) hyvin harvoin. } & \text { [hyvin harvoin. } \\ {[\text { no }} & & \text { very rarely } & \text { [very rarely } \\ \text { [n:o (.) very rarely. } & \text { [very rarely. }\end{array}$

32 Sonja:

[.hh joo

[.hh yeah

33 Maria:

ku ei meit oo kun kaks aikuista [oikeesti

as not we are but two adults [really

as we are only two adults [really.

34 Sonja:

[nii

[yeah

35 Maria: mutta tuota? .hh (.) voishan sitä aatella et se vois olla joku, (.) but erm could+0+indeed it think that it could be some

but erm? .hh (.) you could really think that it could be some, (.)

kevyt, kasviskeitto tai [jotain

light vegetable+soup or[something

light, vegetable soup or[something 


\section{Table6.}

HC5/IV: Member's question to other member is challenging what has been said

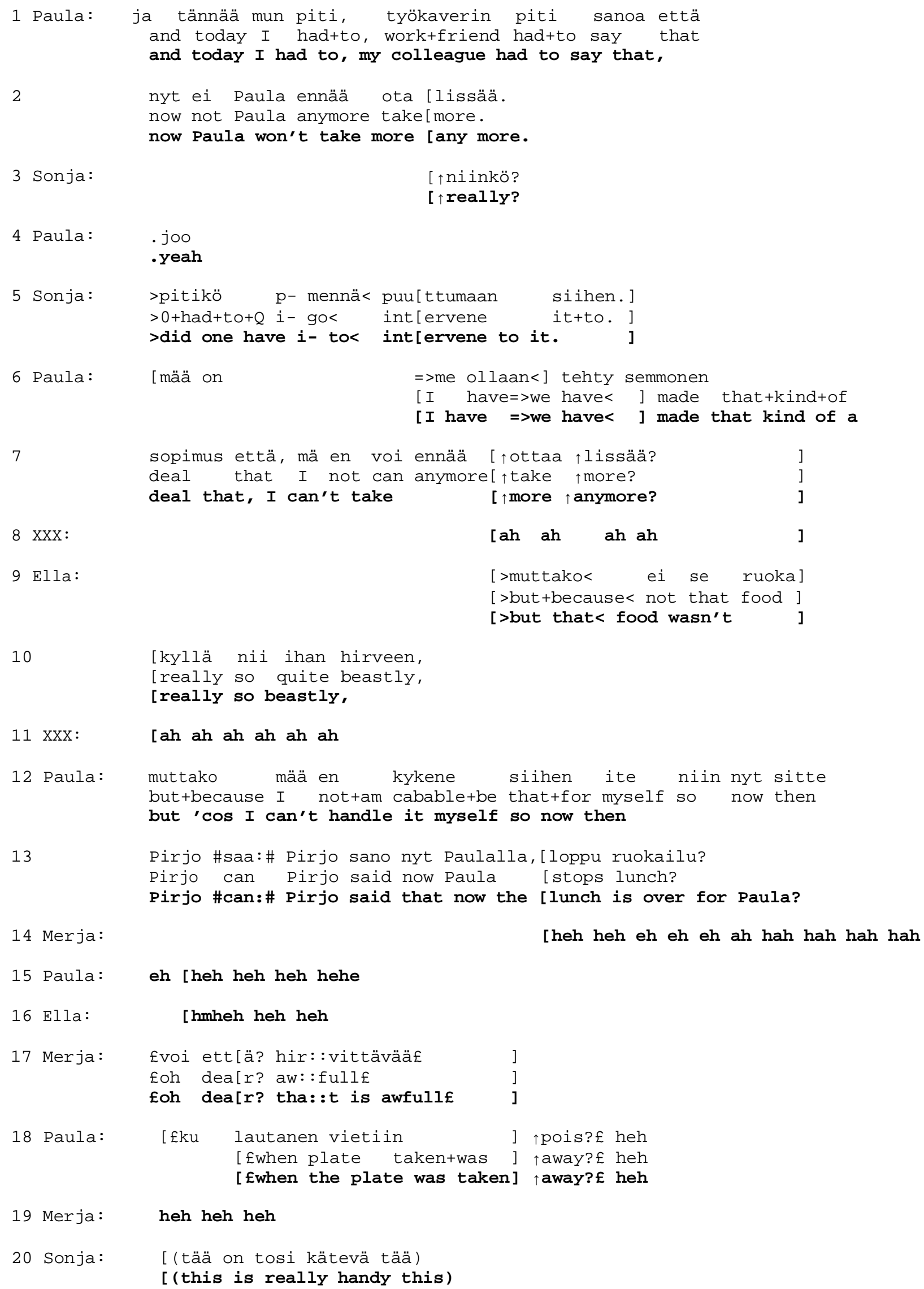




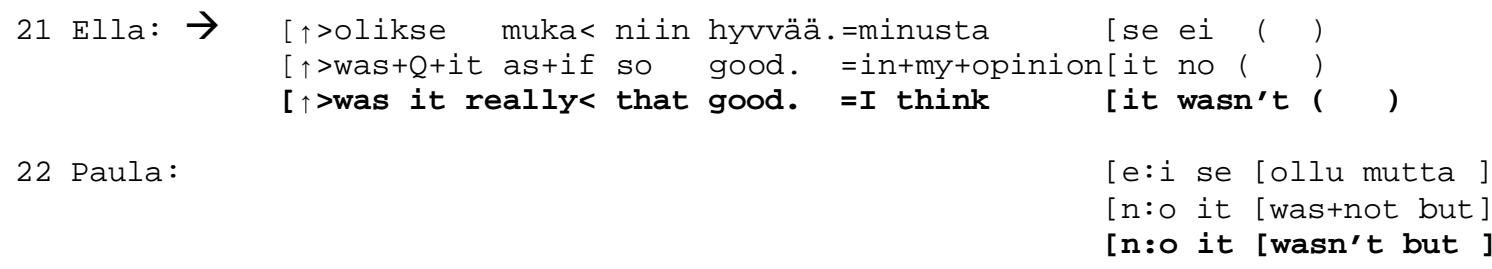

23 Merja:

[se oli maut] onta

[it was tast]eless

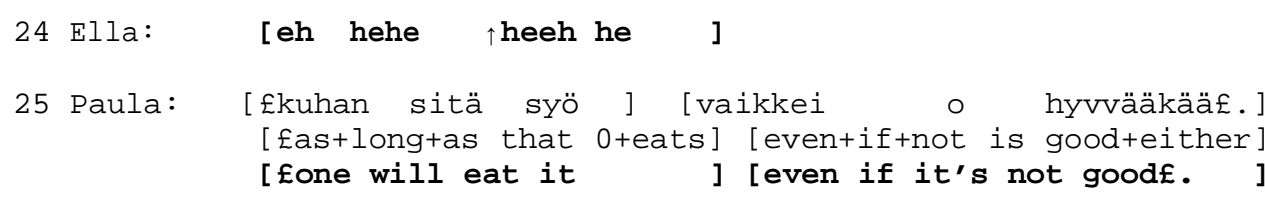

26 Maria:

[ei se hyvvää.

[no it good.

[no it wasn't good.

]

27

$=[$ munki teki mieli mutta en ottanu lissää.

$=[$ mettoo did crave but I+not took more.

$=[I$ craved it too but I didn't take more.

28 Merja: [nii. =mä teen näin just että saako ottaa lissää] $\downarrow$ matonta $\downarrow$ ruokaa.

[yeah. =I do like+that exactly that can 0+take more ] $\downarrow$ tasteless $\downarrow$ food.

[yeah.?=I do exactly like that can one take more of that] $\downarrow$ tasteless $\downarrow$ food.

29 Paula: mhäh ha $\uparrow$ hah hah

30 Merja: [mm eh heh he

31 Ella: [minusta se ei kyllä maistunu.

[in+my+opinion it not really tasted

[I think it didn't really taste.

32 Merja:

ei maistunu

not tasted

[ $\uparrow$ millekkää .

it didn't taste

[ $\uparrow$ anything .

[like $\uparrow$ anything.

33 Paula:

[ei se maistunu mutta]ko [sitähän voi

[no it tasted+not but+be] cause [it+CLI can

[no it didn't but ] [one can well

34 Sonja:

[ (mitä se oli sitte)

[ (what it was then)

35 Paula: syyä silti

eat anyway

eat it anyway

36 Maria: $\quad[(\quad)$

37 Ella: [kinkkukiusausta

[ham casserole

38 Paula: ja (rivakasti) heh heh heh

and (double-quick) heh heh heh

39 Maria: heh hehheh heh 


\section{Table7.}

HC11/II: Member's question to group counsellor is challenging what has been said

1

$(1.0)$

2 Counsellor: eli näitä niinku, jossakin muodossa joka päivä

so these like, sometin formtin every day

so these like, in some form every day

3

ois hyvä olla ( ) (.)

would good be ( ) (.)

it would be good to have ( ) (.)

$\uparrow$ banaania mandariiniä, omenaa. (1.0)

$\uparrow$ banana mandarin, apple. (1.0)

5 tomattia kurkkua, porkkanaa.

tomato cucumber, carrot.

6 Mikko: eikö banaani liho:ta.

not $+Q$ banana fatten.

isn't banana fa:ttening.

7

(1.2)

8 Counsellor: ei se [sen

no it [its

9 Marko:

[elä nyt heti $\quad$ tyrmää
$[$ don't+you now immediatelly knock+out
[don't throw it out right away

[k (h) u ( ) hah hah hah

[don't throw it out right away

() hah hah hah

[wh $(h)$ en () hah hah hah

10 Counsellor:

[heh heh heh

11 Counsellor: s[e:,

$i[: t$,

12 Mikko:

[sitä kuulee kaiken[laista.

[ 0 thears alltki[ndstoftthings.

[one hears all kinds [of things

13 Counsellor:

[se on,

[it is,

15 Harri: $\quad \mathbf{m m}$

16 Counsellor: †semmonen, hirveen vahvassa, (.) oleva usko.

†the+kind+of, terribly strongly (.) existing belief.

$\uparrow$ like a, belief that is (.) terribly strong.

17

$(0.2)$

18 Counsellor: mutta siis, $(0.6)$

but like, $(0.6)$

19

\#ei\# $\uparrow$ siinä banaanissa oo sen enempää energiaa ku on

\#not\# $\uparrow$ that+in bananatin is any more energy than is

\#no\# $\uparrow$ there is no more energy in a banana than there is

20

(0.2) on tuota marjoissa tai (.)

(0.2) is erm berriestin or (.)

$(0.2)$ is erm in berries or (.)

tai niinku omenassakaa et se se on ehkä vähän tiiviimpää että, or like apple+inteither that it it is maybe little denser that, or like in apple either that it it is maybe a little denser that. 


\section{Table8.}

\section{HE1/II: Student's question to teacher is treated as disruption}

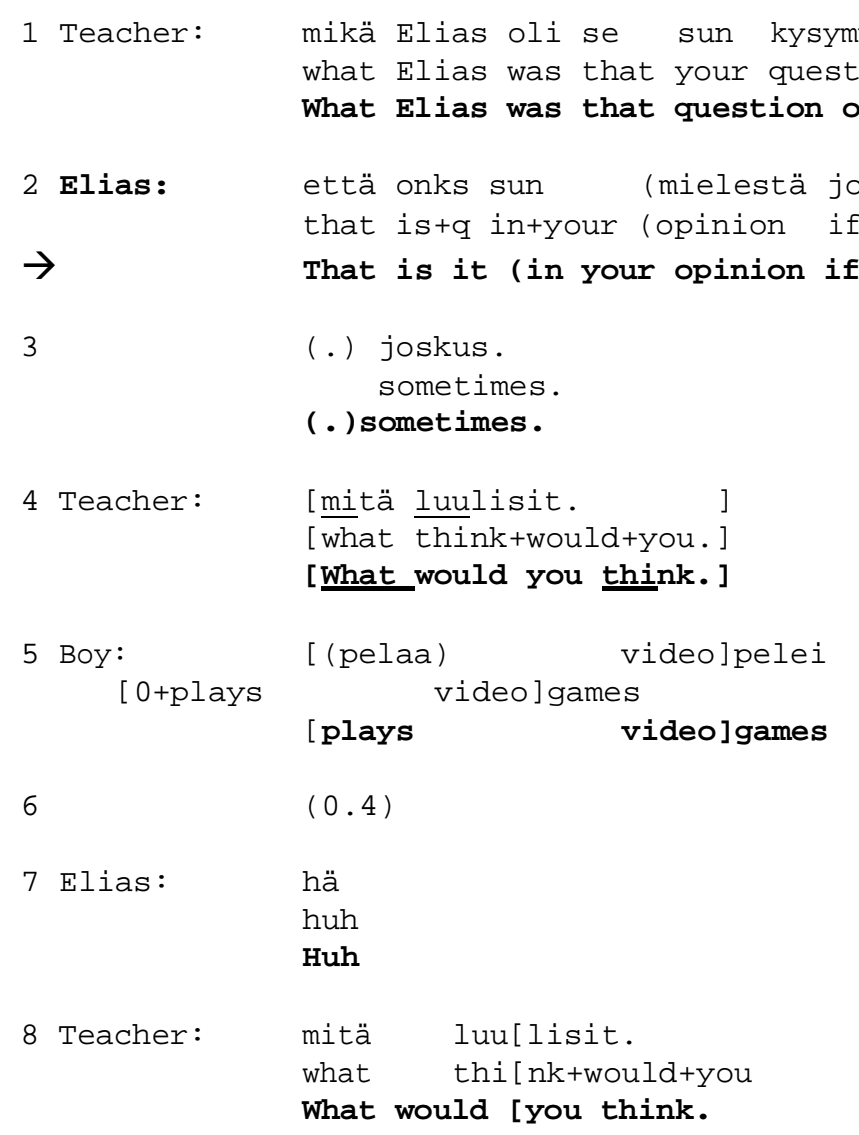

9 Boy:

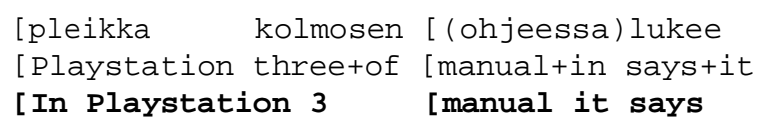

10 Teacher: [onko hyvä.

$$
\text { [istQ good }
$$

[s it good.

11 Boy:

että saattaa saada kouristuksen ja jotkut kuvat

that 0+might get a seizure and some pictures

that one might get a seizure and some pictures
12 Teacher: ei [tietenkään.
no [oftcourse+not.
of [course not.
13 Boy: [jotkut kuviot voi vaikuttaa (että tulee) jotain kouristuksia [some patterns may affect (so+that 0+gets) some seizures
[Some patterns may have an effect (so that one gets) some seizures,
pitää pitää tunnissa vartti taukoa. $0+$ must take hourtin quarter break one must take a quarter break in an hour.
16 Teacher: hei, nyt katse tänne näin, elikkä, täälä on tytöt, ja pojat. hey, now gaze here+to like+this, so, here are girls and boys. Hey, now all eyes on here, so, here are girls, and boys.


ensimmäinen, (0.2) ensimmäinen (.) diagrammi, (.) on, (0.6)

First first

chart

The first, (0.2) the first, (.) chart, (.) is, (0.6)

teevee deeveedee

TV, DVD 


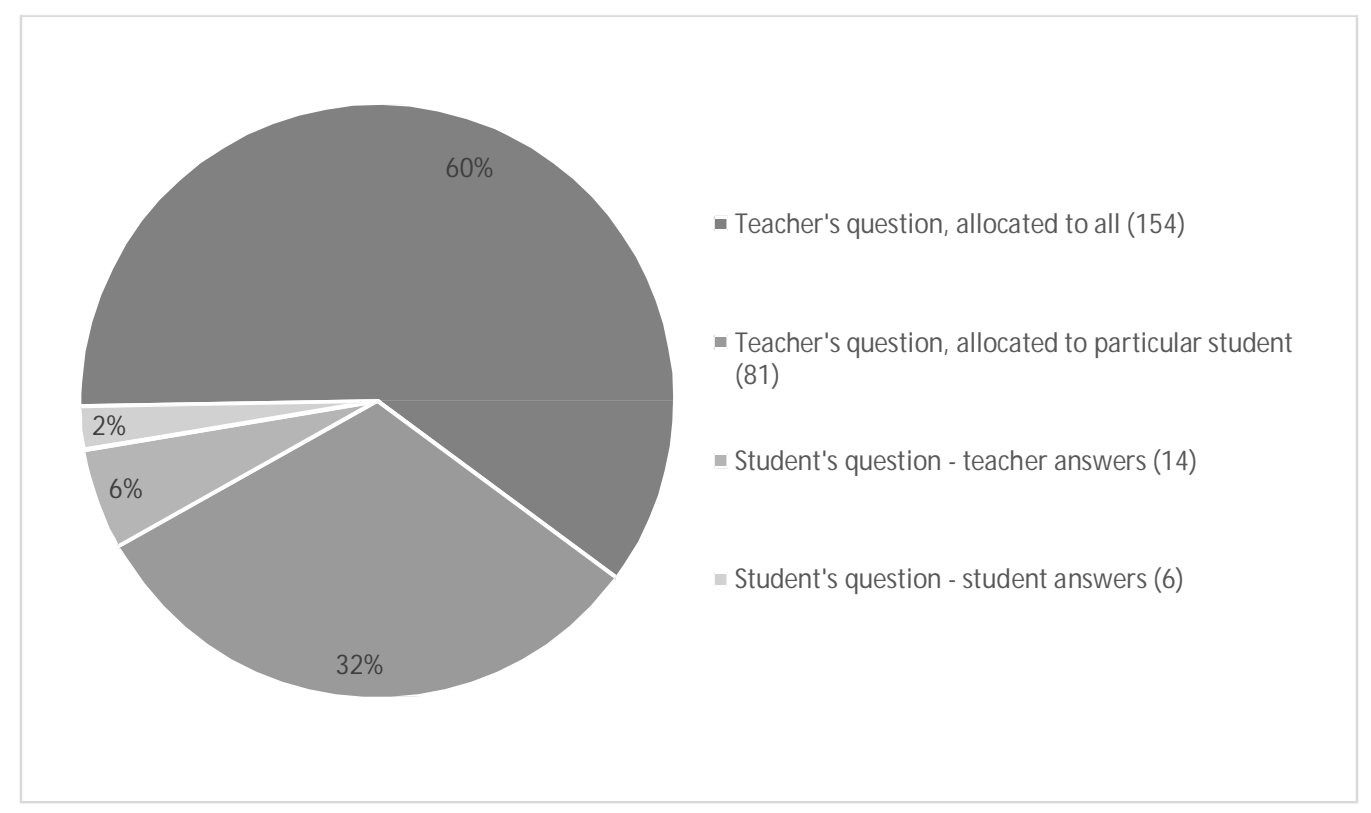

Fig. 1. Number and percentage of teachers' questions and students' questions in three health education lessons

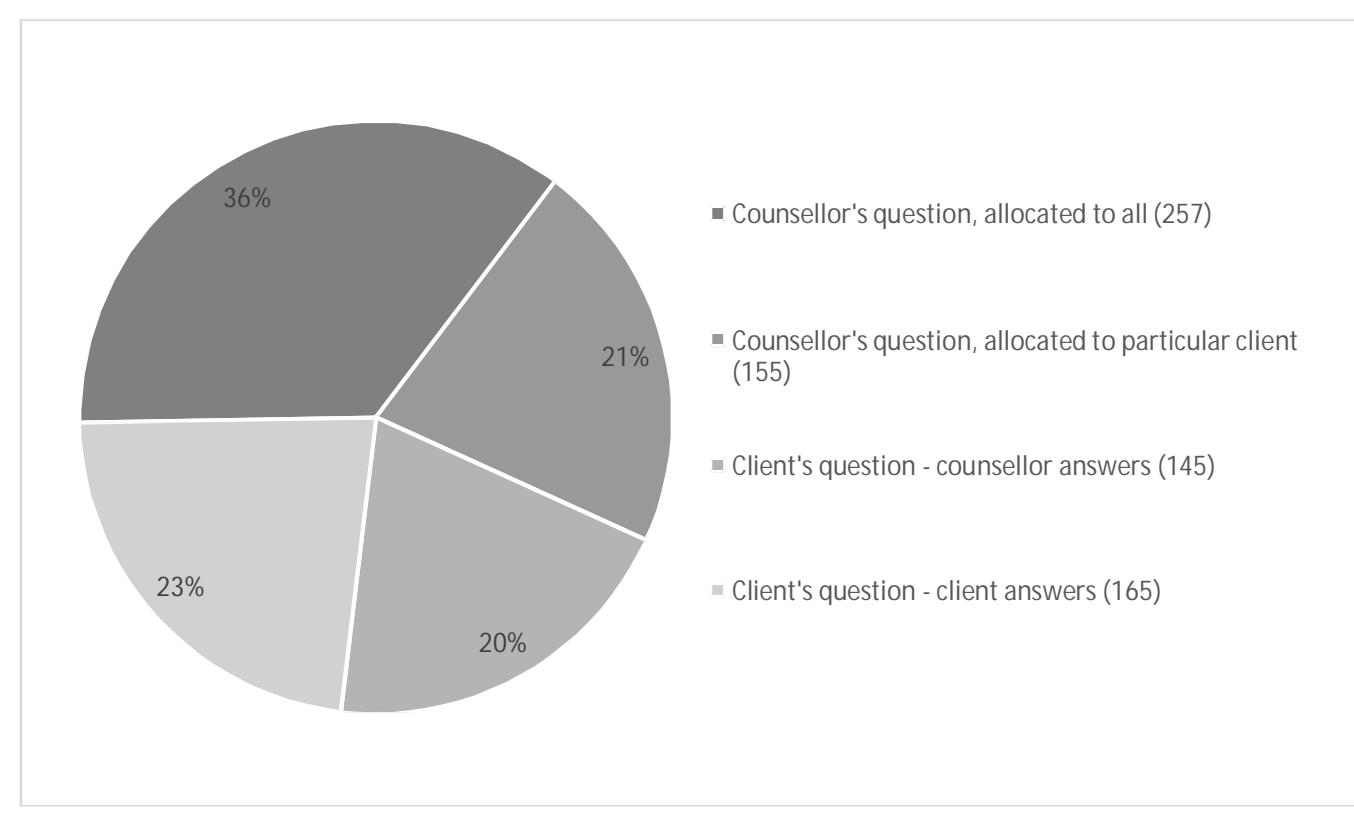

Fig. 2. Number and percentage of counsellors' questions and clients' questions in twelve health counselling sessions. 


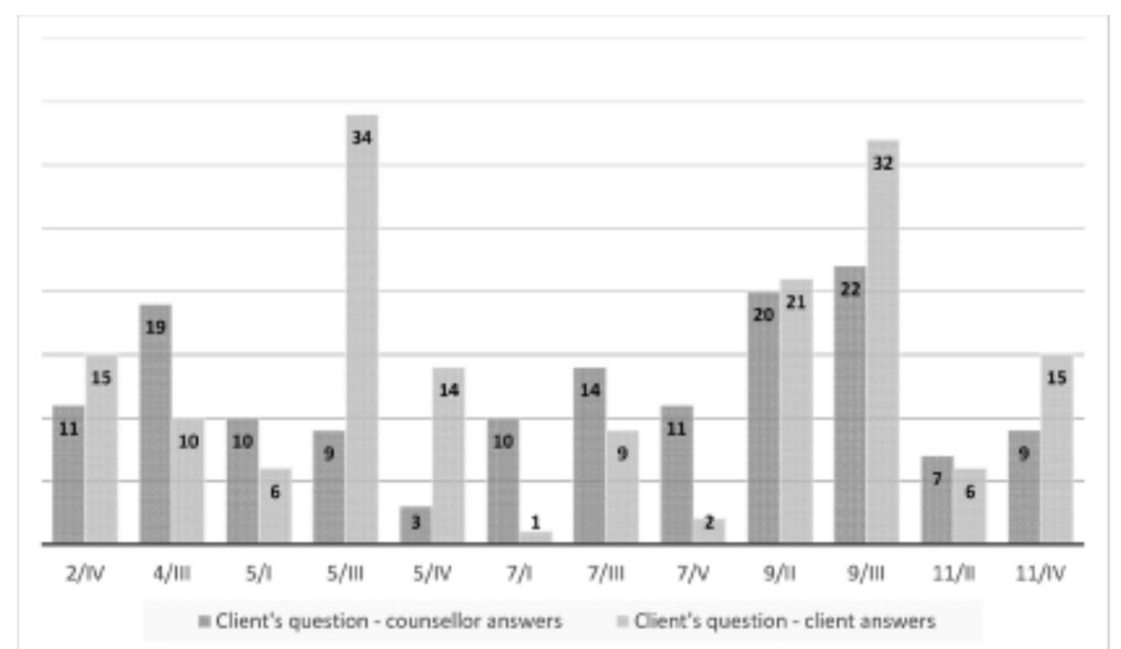

Fig. 3. Comparison of the number of clients' questions in twelve health counselling sessions. The Arabic numeral identifies the group, the Roman numeral identifies the session. 